\title{
050 \\ Assessment of the impact of diuron to water bodies in the Walawa area
}

\author{
R C Watawala ${ }^{2}$, S Liyanage ${ }^{2}$, J A Liyanage ${ }^{1}$ and A P Mallawatantri ${ }^{1}$ \\ 'Department of Chemistry, University of Kelaniya, Sri Lanka \\ 2Department of Chemistry, University of Sri Jayewardenepura
}

Use of pesticides has significantly increased global food production and it is indispensable in modern agriculture to control weeds, insects, other pests and diseases. As the population increases the use of pesticides also increases. The impact of these pesticides to the environment is not well understood for Sri Lankan conditions Hence the sorption pattern of a non ionic pesticide, diuron \{3-(3,4dichlorophenyl)-1,1-dimethylurea; $\mathrm{C}_{9} \mathrm{H}_{1} \mathrm{Cl}_{2} \mathrm{~N}_{2} \mathrm{O}$ \} which is used as a herbicide tp control weeds and mosses mainly in sugarcane, was studied for 14 soil series in the right bank of the Walawa basin in Sri Lanka.

Information was collected from farmers in Walawa areas on crops, historical cropping patterns, type of pesticides used, pesticides handling knowledge etc. The survey revealed that pesticides use is malpracticed by farmers. The distribution of crop types in the area during last three years shows that Paddy, which is scattered through out the area, is the most prominent crop. The average area under paddy cultivation is approximately 9800 ha. Banana was the second highest grown crop that is in about $4200 \mathrm{ha}$. Sugarcane, which covers about $2500 \mathrm{ha}$, is the prominent monoculture in the Walawa basin.

Adsorption of diuron to the collected surface $(0-10 \mathrm{~cm})$ soils of the 14 soil series in the Walawa basin were measured using High Performance Liquid Chromatographic method. The Moraketiya series showed the highest sorption among them. It also gives the highest $\mathrm{Kd}$ value of the selected soils and Sivambala series exhibited the lowest adsorption and $\mathrm{Kd}$. The organic carbon content was highest in Kachigalara series and it was lowest in the Walawa series. The measured Kd values were used to predic the risk of this pesticide to ground and surface water in the Walawa area using a simple management model called Pesticide Impact Rating Index, PIRI which resulted a moderate risk for the contamination of water bodies in the area.

\section{1 \\ Environ.nental impacts on waste and water disposal from abbatoirs and poultry processing units in Weligama area.}

\author{
N D C Sirisena, P A B S Baduwasam, R A U J Marapana and T Seresinghe \\ Department of Animal Science, University of Ruhuna, Sri Lanka
}

Selling of M€s: 's one of the popular businesses among the Muslim community in the Weligama area. Therefcre, the opjective of the present study was to collect baseline data on the waste and water disp. $30^{-1}$ methods and sanitary measures in abattoirs and poultry farms in the area. Selected abattoirs and poultry farms were visited to monitor the prevailing conditions and advice abattoirs and poultry farmers how to improve the standards in their working places. The results of this study revealed that ail the abattoirs possess experience but little skil!, knowledge and technology. All the visited abattoirs are situated close to residential areas, especially close to water bodies such as wells and streams. The reason is that the abattoirs need lot of water for cleaning and other purposes. Animals were killed on the floor just after cleaning with water. Approximately $100-150 \mathrm{~kg}$ meat was processed daily. The carcass recovery percentage was $50 \%$; thereby waste generated was also $50 \%$ of the live weight of the animal. Approximately half of the waste contained bones, buried and used as fertilizer at a latter stage. Inedible parts of the digestive track and undigested material also buried, however, very close to the proximity of residential areas. The amount of water used was around $80-1001 /$ day but no proper way of disposing polluted water as it directly gces to drains, streams and opened wells etc. It was also observed that all the potiltry cages and processing units were located very close to residential areas. Around $300 \mathrm{~kg}^{\dagger}$ of poultry meat was preduced daily. The carcass recovery was around $70-75 \%$ while the amount of waste generated was $25-30 \%$ of the live weight of a bird. Average waste material gener'ated from a processing unit was around $75 \mathrm{~kg} /$ day. The offal's were properly disposed due to collection by the urban council for compost making. It prevents environmental pollution and health

Proceedings of the International Forestry and Environment Symposiun 2006 of the

Department of Forestry and Environmental Science. University of Sri Jayewardmon,it, Sy Lanka 